\title{
PENINGKATAN MINAT DAN HASIL BELAJAR SISWA MATERI PEWARISAN SIFAT MELALUI METODE KONSEPTUAL KELAS IX SMP NEGERI 1 SUGIHWARAS BOJONEGORO TAHUN PELAJARAN 2020/2021
}

\author{
BILAL \\ SMP Negeri 1 Sugihwaras \\ e-mail : moenadjibilal@gmail.com
}

\begin{abstract}
ABSTRAK
Penelitian ini memiliki tujuan untuk mengetahui sejauh mana penerapan Metode Konseptual dalam meningkatkan minat belajar dan hasil belajar siswa mata pelajaran IPA KELAS IX A SMP Negeri 1 Sugihwaras Kabupaten Bojonegoro Propinsi Jawa Timur Semester Ganjil Tahun Pelajaran 2020/2021pada topik Perkawinan Silang. Jenis Penelitian ini adalah Penelitian Tindakan Kelas (PTK). Penelitian tindakan kelas ini menggunakan tiga siklus, tiap siklus menggunakan empat tahap, yaitu perencanaan, pelaksanaan, observasi, dan refleksi. Pada akhir setiap siklus dilaksanakan tes dengan menggunakan instrumen soal. Kemudian hasil yang diperoleh pada siklus pertama, kedua, dan ketiga dirata-rata untuk menjadi hasil akhir dari setiap siklus.apabila melihat data terdapat kenaikan dari siklus I ke siklus II, siklus I ketuntasan mencapai $25 \%$ naik menjadi $68 \%$ pada siklus II. Selanjutnya dari siklus II ke siklus III juga mengalami kenaikan, pada siklus II ketuntasan mencapai $68 \%$ naik pada siklus III menjadi 91 $\%$. Siswa yang belum mencapai KKM pada siklus I mencapai 23 siswa atau $75 \%$ berkurang pada siklus II yaitu tinggal 10 siswa, berkurang $43 \%$ dan pada siklus III hanya tinggal 3 siswa. Berarti terjadi peningkatan ketuntasan belajar pada siswa dan jumlahnya mencapai 91. Berdasarkan hasil penelitian, maka dapat disimpulkan bahwa dengan menggunakan Metode Konseptual dapat meningkatkan minat dan hasil belajar siswa Kelas IX A SMP Negeri 1 Sugihwaras Kabupaten Bojonegoro Jawa Timur Semester Ganjil Tahun Pelajara 2020/2021 pada materi IPA topik pewarisan sifat.
\end{abstract}

Kata Kunci : pewarisan sifat, hasil belajar metode konseptual

\section{PENDAHULUAN}

Bekal yang dibutuhkan untuk menghadapi perkembangan kehidupan lewat kecanggihan ilmu dan tehnologi adalah berupa ilmu pengetahuan dan tehnologi, hal ini bisa diartikan harus ada pembaharuan dalam pendidikan (Astuti dkk, 2017). Dengan perkembangan ilmu pengetahuan dan tehnologi, maka pendidikan juga harus mengalami perkembangan kemampuan berpikir, agar peserta didik mengalami keberhasilan. Ada beberapa faktor yang mempengaruhi keberhasilan mutu pendidikan dalam proses pembelajaran IPA diantaranya adalah guru, siswa, jumlah siswa, fasilitas pembelajaran, da metode pembelajaran. "Pembelajaran dapat berjalan dengan sukses dan lancar ditentukan oleh beberapa unsur diantaranya guru, siswa, kurikulum, sarana prasarana, tujuan, metode pembelajaran, lingkungan yang mendukung, dan penilaian (Agus S. Suryobroto, 2004).

Peningkatan mutu pendidikan juga dapat dicapai melalui berbagai cara, antara lain melalui peningkatan kualitas pendidik dan tenaga kependidikan lainnya, pelatihan dan penyelesaian masalah pemebelajaran secara profesional. "Proses pembelajaran merupakan pokok utama dari keseluruhan proses pendidikan, karena melalui sebuah proses pembelajaran terjadi transfer ilmu dari guru ke peserta didik yang berisi berbagai tujuan pendidikan. Salah satu dari tujuan pendidikan IPA di SMP adalah melakukan inkuiri ilmiah untuk menumbuhkan kemampuan berpikir dan bertindak ilmiah (Rohim, dkk, 2012 ).

Guru merupakan tenaga pendidik yang menpunyai tugas mulia dan tanggung jawab yang besar berkaitan dengan perkembangan anak didik agar terlepas dari kebodohan sehingga guru dituntut profesional dalam mengajar. Dalam proses belajar mengajar selalu melibatkan guru sebagai arsitek pembelajaran dan anak didik sebagai penikmat pembelajaran, maka pembelajaran yang dilakukan oleh guru harus bisa diterima siswa dengan mudah dan 
membangkitkan semangat belajar anak didik. Hal ini berarti berhasil dan tidaknya tujuan pendidikan tergantung dari bagaimana guru merancang proses belajar mengajar secara maksimal sehingga peserta didik mampu menerima pembelajaran dengan mudah, termasuk diantaranya memilih model pembelajaran yang tepat, sehingga anak didik mudah memahami materi pelajaran yang diberikan guru.Untuk itu guru mampu menggunakan model, strategi, dan media pembelajaran yang tepat (Prasetyarini dkk, 2013).

Upaya mencapai tujuan pembelajaran IPA masih menemui kesulitan, salah satu kesulitan itu penyebabnya adalah penggunaan metode pembelajaran yang kurang tepat, sehingga pembelajaran kurang efektif, pembelajaran sering menekankan pada aspek mengingat, memahami dan mengaplikasikan. Tantangan ke depan menuntut pembelajaran harus lebih mengembangkan keterampilan berpikir ( Mikran dkk, 2018).

Pada proses belajar dan evaluasi pembeajaran di kelas IX A semester ganjil SMP Negeri 1 Sugihwaras tahun pelajaran 2020/2021 pada pelajaran IPA konsep pewarisan Sifat pada Makhluk Hidup menunjukkan tingkat penalaran dan kemampuan memecahkan masalah yang rendah. Hal ini dibuktikan juga dengan perolehan hasil belajar sebelumnya yang kurang memuaskan. Kelas yang jumlah siswanya 31 orang, hanya terdapat 10 anak yang mencapai Standar Ketuntasan Belajar Minimal (SKBM =75), sedang 21 siswa lainnya berada di bawah standar ketuntasan belajar minimal. Ini menunjukkan siswa kurang mampu menyerap materi pelajaran yang diajarkan. Ini menunjukkan bukti bahwa minat belajar siswa sangant rendah. Untuk mencapai pembelajaran yang baik guru dituntut untuk memiliki proses pembelajaran yang efektif. Pembelajaran efektif terwujud jika guru menerapkan strategi pembelajaran yang tepat (Imaduddin, dkk, 2014). Pendidik yang berkualitas diharapkan mampu meningkatkan pengetahuan, keterampilan, dan pemahaman peserta didik.

Sesuai dengan permasalahan yang diuraikan tersebut, guru mencoba menerapkan suatu model pembelajaran yang dapat meningkatkan minat belajar dan hasil belajar pelajaran IPA yaitu dengan menerapkan metode konseptual, sehingga diharapakan minat belajar serta hasil belajar siswa meningkat.

\section{METODE PENELITIAN}

Penelitian yang digunakan adalah Penelitian Tindakan Kelas (PTK), yaitu penelitian yang diharapkan bisa memberikan sumbangsih untuk meningkatkan keprofesionalan bagi guru, serta mempersiapkan pemahaman, pengetahuan, serta wawasan guru dan peserta didik dalam pembelajaran. Penelitian ini menggunakan empat tahapan, yaitu (1) persiapan, (2) pelaksanaan, (3) pengamatan, dan (4) refleksi.

Penelitian Tindakan Kelas ini dilakukan di SMP Negeri 1 Sugihwaras Kabupaten Bojonegoro Propinsi Jawa Timur pada Tahun pelajaran 2020/2021 Semester ganjil. Penelitian ini dilakukan pada siswa kelas IX A yang jumah siswanya 31 siswa.

Penelitian Tindakan Kelas ini menggunakan Metode Konseptual dalam pembelajarannya, semua data sepenuhnya diambil dari siswa yang kelasnya dipakai objek dalam penelitian tindakan kelas (PTK). Kriteria keberhasilan Penelitian Tindakan Kelas ini bisa dilihat dari kegiatan proses pembelajaran maupun hasil evaluasi belajar. Keberhasilan Penelitian Tindakan Kelas (PTK) dikatakan berhasil apabila keberhasilannya mencapai minimal $80 \%$

\section{HASIL DAN PEMBAHASAN}

\section{Hasil}

Berdasarkan data yang didapat dari siklus I, didapat hasil bahwa dari 31 peserta didik terdapat 8 peserta didik atau $25 \%$ yang mendapat nilai sama atau di atas ktiteria Ketuntasan Minimal (KKM) yaitu nilai 75, ini dapat dikatakan telah mencapai ketuntasan belajar, sedang sisanya yang mendapatkan nilai di bawah Kriteria Ketuntasan Belajar Minimal (KKM) ada 23 peserta didik atau $75 \%$, ini dikatakan siswa tersebut belum tuntas belajar, karena dikatakan tuntas belajar jika pada kelas tersebut $80 \%$ tuntas belajarnya. Mencermati hasil belajar siswa maka dapat dibuat tabel ketuntasan dan diagram hasil belajar siswa pada siklus I sebagai berikut 
Tabel 1. Ketuntasan Hasil belajar siklus I

\begin{tabular}{|c|c|c|c|}
\hline No. & Ketuntasan & Peserta Didik & Prosentase \\
\hline 1 & tuntas & 8 & $25 \%$ \\
\hline 2 & Belum tuntas & 23 & $75 \%$ \\
\hline & Jumlah & 31 & $100 \%$ \\
\hline
\end{tabular}

\section{Peserta Didik}

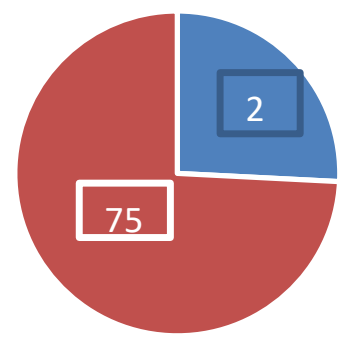

- tuntas - Belum tuntas

\section{Gambar 1. Diagram Ketuntasan Hasil belajar siklus I}

Maka dapat disimulkan bahwa penguasaan peserta didik pada mata pelajaran IPA materi perkawinan silang sangat rendah. Untuk itu perlu melakukan siklus II guna memperbaiki hasil belajar yang masih rendah.

Berdasarkan data yang di dapat pada siklus II diperoleh hasi dari 31 siswa terdapat 21 siswa atau $68 \%$ yang telah mendapat nilai di atas Kriteria Ketuntasan Minimal (KKM), sedang sisanya yaitu 10 siswa atau $32 \%$ mendapat nilai di bawah Kriteria Ketuntasa Minimal (KKM). Ini dapat dikatakan bahwa siswa belum tuntas dalam belajar IPA materi perkawinan silang. Melihat dari data hasil belajar siswa maka dapat dibuat tabel ketuntasan dan diagram sebagai berikut :

Tabel 2. Ketuntasan Hasil belajar siklus II

\begin{tabular}{|c|c|c|c|}
\hline No. & Ketuntasan & Peserta Didik & Prosentase \\
\hline 1 & tuntas & 21 & $68 \%$ \\
\hline 2 & Belum tuntas & 10 & $32 \%$ \\
\hline & Jumlah & 31 & $100 \%$ \\
\hline
\end{tabular}

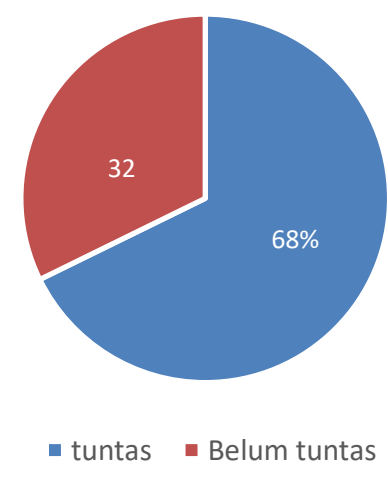

Gambar 2. Diagram Ketuntasan Hasil belajar siklus II

Dari data yang di dapat pada siklus II terdapat perbaikan hasil belajar bila dibanding pada siklus I, yaitu rata-rata mencapai $68 \%$. Ini bisa dikatakan pembelajaran belum tuntas karena belum mencapai $80 \%$, untuk itu perlu dilakukan perbaikan pembelajaran agar ketuntasan bisa dicapai, maka perlu dilakukan siklus III. 
Berdasar data yang didapat dari siklus III, dari 31 siswa ada 28 siswa atau $91 \%$ yang memperoleh nilai di atas Kriteria Ketuntasan Minimal (KKM) yaitu 75 dan dikatakan peserta didik sudah mencapai ketuntasa belajar, sedang peserta didik yang mendapat nilai di bawak kriteria ketunasan minimal (KKM) ada 3 anak atau 9,9\%, ini berarti 3 siswa tersebut belum tuntas belajar. Berdasar data di atas maka peserta didik dikatakan telah tuntas dalam belajar IPA materi perkawinan silang karena siswa yang mendapat nilai di atas Kriteria Ketuntasan Belajar telah mencapai $91 \%$, berarti telah mencapai lebih dari $80 \%$. Berikut tabel Ketuntasan dan Diagram hasil belajar siswa pada siklus III

Tabel 3. Ketuntasan hasil belajar siklus III

\begin{tabular}{|c|c|c|c|}
\hline No. & ketuntasan & Peserta didik & prosentase \\
\hline 1 & tuntas & 28 & $91 \%$ \\
\hline 2 & Belum tuntas & 3 & $9 \%$ \\
\hline & Jumlah & 31 & $100 \%$ \\
\hline
\end{tabular}

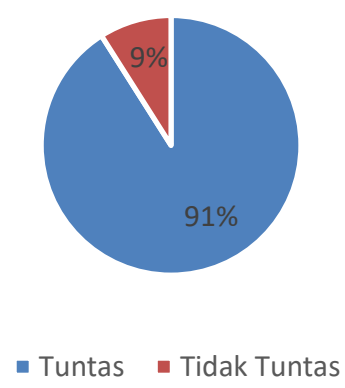

Gambar 3. Diagram Ketuntasan hasil belajar siklus III

\section{Pembahasan}

Pelaksanaan proses pembelajaran pada siklus I peneliti menerapkan konsep pembelajaran sesuai rencana pembelajaran (RPP), diperoleh hasil siswa banyak yang belum tuntas dalam belajar atau siswa banyak yang belum tuntas.

Pelaksanaan pembelajaran pada siklus II, menunjukkan poses pembelajaran dengan menggunakan metode pembelajaran yang direncanakan belum sepenuhnya berhasil, ini ditunjukkan dengan minat siswa yang belum maksimal dalam pembelajaran ini ditandai dengan persiapan awal yang memakan waktu lama, tetapi setelah pembelajaran selanjutnya siswa mulai menunjukkan semangat dalam pembelajaran.

Pada proses pembelajaran di siklus III siswa sudah mulai terbiasa melaksanakan pembelajaran dengan metode pembelajaran konseptual, ini ditandai dengan semakin besarnya semangat belajar siswa dengan dibuktikan pada hasil belajar siswa yaitu nilai siswa yang lebih dari kriteria ketuntasa minimal.dengan demikian proses pembelajaran dengan metode konseptual dapat membawa perubahan pada siswa.

Dari hasil belajar siswa mulai dari siklus I sampai siklus III menunjukkan ada peningkatan hasil belajar siswa pelajaran IPA konsep pewarisan sifat yang sangat signifikan, maka hepotesa terbukti, bahwa dengan penerapan metode konseptual dapat meningkatkan minat belajar dan hasil belajar IPA kelas IX A SMP Negeri 1 Sugihwaras Kabupaten Bojonegoro.

\section{KESIMPULAN}

Hasil belajar IPA pada topik Pewarisan Sifat dengan menggunakan metode pembelajaran yang tepat dapat meningkatkan hasil belajar siswa, ini dapat dilihat dari perubahan hasil belajar dari siklus I sampai siklus III mengalami perbaikan hasil belajar yang siknifikan, siklus I hanya $25 \%$ dari total 31 siswa yang tuntas belajar, $68 \%$ pada siklus II yang 
tuntas, dan $91 \%$ yang tuntas belajar pada siklus III. Ini menandakan $91 \%$ siswa sudah mendapatkan hasil di atas KKM.

Dengan penerapan metode pembelajaran, yaitu metode konseptual, mampu meningkatkan minat dan hasil belajar siswa. Hal ini selaras dengan apa yang disampaikan oleh Agus S. Suryobroto (2004), bahwa salah satu faktor yang mempengaruhi pembelajaran adalah metode pembelajaran.

\section{DAFTAR PUSTAKA}

Agus S. Suryobroto. (2004). Diktat kuliah sarana dan prasarana pendidikan jasmani.

Astuti, I A D, Sumarni, R, A. (2017). Pengembangan media pembelajaran fisika mobile lerning berbasis android. Jurnal Penelitian \& pengembangan pendidikan fisika. 3 (1), 57-62

Idayanti, I. Darsono, T, \& Naini, B. (2019). pengembangan tes Diagnostik menggunakan Certaintyof Response Index (CRI) termdifikasi pada materi tekanan zat untuk siswa kelas VIII SMP. UPEJ Unnes Physics Education Journal. 8 (1), 22 - 27.

Imaduddin, M, Hidayah F. F \& Astuti, A. P. (2014). Deskripsi pedagogical Content Knowledge Guru kimia Menggunakan Komponen Model pentagon. jurnal Sains. 2 (I), 26-35.

Mikran M, Pasaribu, M, \& Darmadi, I. W. (2018). Penerapan model pembelajaran Kooperatif Make a Match untuk meningkatkan hasil belajar siswa. (Jurnal pendidikan fisika Tadulako Online). 2 (2), 9-16

Prasetyarini, A, Fatmaryanti, S. D. (2013). pemanfaatan alat peraga IPA untuk meningkatkan pemahaman konsep fisika pada siswa SMP Negeri 1 Buluspesantren Kebumen tahun pelajaran 2012/2013. RADIASI : Jurnal berkala pendidikan fisika. 2 (1), 7 - 10

Rohim F, \& Susanto H. (2012). Penerapan model discovery terbimbing pada pembelajaran fisika untuk meningkatkan kemampuan berpikir kreatif. UPEJ. Unnes Physics Education Journal. 1 (1). Yogyakarta : FIK - UNY 